УДК 347.9

DOI https://doi.org/10.32849/2663-5313/2020.4.09

Ірина Тимошевська,

канд. юрид. наук,

асистент кафедри иивільного процесу

Національного юридичного університету імені Ярослава Мудрого

\title{
УПОВНОВАЖЕНИЙ \\ ВЕРХОВНОЇ РАДИ УКРАЇНИ \\ 3 ПРАВ ЛЮДИНИ ЯК УЧАСНИК СУДОВОГО ПРОЦЕСУ
}

Стаття присвячена вивченню питань правового статусу Уповноваженого з прав людини як учасника иивільного процесу за законодавством різних держав світу та проблем розмежування діяльності омбудсмена й судової системи.

Автором статті детально проаналізовано правовий статус Уповноваженого з прав людини взагалі та як учасника цивільного процесу, зокрема за законодавством Швеиії, Австралії, Польщі, Великої Британії, Європейського Союзу, Украӥни; виділено особливості й характерні риси, притаманні нормативному регулюванню його діяльності в кожній державі.

У статті акцентовано увагу на рекомендаціях Парламентської асамблеї Ради Свропи щодо забезпечення чіткого розподілу компетениій між інституиіями омбудсмена й судовою системою. А також на рекомендачіях Венечіанської комісії щодо взаємовідносин омбудсмена з начіональними судами. Згідно з наданими рекомендачіями правовий статус у взаємовідносинах омбудсмена з конституиійними судами істотно відрізняється від його правового статусу під час взаємодії з судами загальної юрисдикиії. Зокрема наголошується на збереженні нейтралітету омбудсмена й забезпеченні незалежності судової системи, насамперед ідеться про суди загальної юрисдикиії.

Окремо автором розглянуто особливості нормативно-правового регулювання й доктринально$2 о$ визначення правового статусу Уповноваженого Верховної Ради України з прав людини як учасника иивільного прочесу й аргументовано, що найбільший правозахисний потенціал Уповноваженого міститься в його праві звертатися до суду з заявою про захист прав і свобод осіб, які через фізичний стан, недосягнення повноліття, похилий вік, недієздатність або обмежену дієздатність не можуть иього зробити самостійно, а також особисто або через свого представника брати участь у судовому проиесі.

У статті підсумовано, що Уповноважений з прав людини вправі звертатися до суду за захистом порушених прав та інтересів громадян, проте має обгрунтувати суду неможливість особи самостійно здійснювати захист своїх інтересів і надати відповідні документи на підтвердження вказаних обставин, оскільки діяльність омбудсмена не має заважати судовій системі та його втручання до неі має бути мінімальним.

Ключові слова: Уповноважений з прав людини, омбудсмен, цивільний процес.

Постановка проблеми. Відповідно до ст. 101 Конституції України парламентський контроль за додержанням конституційних прав і свобод людини та громадянина здійснює Уповноважений Верховної Ради України з прав людини (далі - Уповноважений). Закон України «Про Уповноваженого Верховної Ради України з прав людини» від 23 грудня 1997 р. регулює правовий статус українського правозахисника [1].

Метою статті є розгляд правового статусу Уповноваженого Верховної Ради України з прав людини як учасника цивільного процесу.
Виклад основного матеріалу. Питанням правового статусу Уповноваженого з прав людини та його участі в цивільному процесі свої праці присвятили такі вчені як Бойцова В., Грошевий Ю., Косюта М., Марцеляк О., Ненашев М., Тацій В., Тенебаум А., Цвік М. та ін.

Уповноважений з прав людини у світі став відомий під назвою «омбудсмен». Омбудсмен (швед. ombudsman) - це посадова особа, якій надається право представляти інтереси громадськості. Для омбудсмена дуже важливий рівень незалежності. У деяких країнах генеральний інспектор, адвокат громадянина або інша посадова 
особа може виконувати обов'язки, аналогічні обов'язкам національного омбудсмена. Використання терміна «омбудсмен» в його сучасному значенні почалося в Швеції, коли парламентським омбудсменом для захисту прав громадян був запроваджений урядовим актом 1809 р. наглядовий орган, незалежний від виконавчої влади. Попередником шведського парламентського омбудсмена була Канцелярія Верховного омбудсмена (H gste Ombudsmannen), яка була заснована шведським королем Карлом XII у 1713 р. Карл XII перебував у вигнанні в Туреччині й потребував представника у Швеції, щоб судді й державні службовці діяли відповідно до законів і своїх обов'язків. Верховний омбудсмен мав право переслідувати їх за неналежне виконання обов'язків. У 1719 р. канцелярія Верховного омбудсмена Швеції стала канцлером юстиції. Парламентський омбудсмен був створений в 1809 р. шведським риксдагом як паралельний інститут для все ще чинного канцлера юстиції, що відображає концепцію поділу влади, розроблену Монтеск'є [2].

У багатьох країнах, де в обов'язки омбудсмена входить захист прав людини, омбудсмен визнаний національною правозахисною установою. Пост омбудсмена був заснований більшістю урядів і деякими міжурядовими організаціями, такими як Європейський Союз, до кінця ХХ ст. Першого Уповноваженого $з$ прав людини в Україні було призначено на посаду в 1998 р.

В Україні Уповноважений призначається Верховною Радою України та є незалежним, політично нейтральним, одноособовим органом державної влади, уповноваженим за власною ініціативою, зверненням громадян України, осіб без громадянства чи їх представників або народних депутатів України здійснювати на постійній основі контроль за додержанням конституційних прав і свобод людини й громадянина та захист прав кожного на території України й у межах її юрисдикції, керуючись у своїй діяльності Конституцією України, законами України, чинними міжнародними договорами, згода на обов'язковість яких надана Верховною Радою України [3, с. 38].

Як зазначено в ст. 2 Закону України «Про Уповноваженого Верховної Ради України 3 прав людини», юрисдикція Уповноваженого поширюється на відносини, що виникають за реалізації прав і свобод людини й громадянина між громадянином України, незалежно від місця його перебування, іноземцем чи особою без громадянства, які перебувають на території України, та органами державної влади, органами місцевого самоврядування та їх посадовими й службовими особами. Як зазначалось в літературі, юрисдикція Уповноваженого не поширюється на права солдатів та інших військовослужбовців - громадян України [4, с. 102].

Уповноважений здійснює шляхом участі в цивільному процесі захист прав громадян, порушених у результаті дій чи бездіяльності органів державної влади, органів місцевого самоврядування, посадових і службових осіб. Між тим, у законодавстві відсутня чітка регламентація підстав і форм такої його участі, відсутні й фундаментальні наукові дослідження з цього питання.

Немає жодних винятків в законодавстві щодо обмеження юрисдикції Уповноваженого, а тому предметом його контролю є діяльність усіх посадових і службових осіб органів державної влади та місцевого самоврядування, у тому числі підпадає під юрисдикцію Уповноваженого й діяльність судів. Безумовно, суди у своїй діяльності є незалежними й під час здійснення своїх функцій підкоряються лише закону й не можуть зазнавати жодного впливу. Тому контрольні функції Уповноваженого щодо діяльності суддів стосуються не суті судових рішень, а пов'язані, зокрема, з порушенням термінів розгляду справ у судах, недотриманням процесуальних норм тощо.

Наприклад, у Південній Австралії Омбудсмен не існує як засіб оскарження рішення органу, з яким ви не згодні. Омбудсмен має стежити за тим, щоб процес був розумним і справедливим, а також, щоб рішення не було незаконним, необгрунтованим або неправильним [5].

У Великій Британії до Омбудсмена можна звернутися і він буде розглядати справу тільки в тому випадку, якщо людина зазнала особисту несправедливість, труднощі або фінансові втрати через дії або бездіяльність конкретного органу. Послуги Омбудсмена частіше називаються методами альтернативного вирішення спорів (ADR) [6].

У Польського Уповноваженого є широкий спектр інструментів, за допомогою яких він може впливати на правоохоронні й судові органи. Особлива увага приділяється участі в судових процесах.

У цивільних справах (сімейних, трудових і пов'язаних з соціальним страхуванням) Уповноважений може подати позов до суду, а потім брати в ньому участь як сторона (п. п. 4, 6 ст. 14 Закону «Про омбудсмена») [7].

Як свідчить аналіз звернень щодо порушення прав громадян України судовими органами, типовими є скарги на тяганину під час розгляду судом позовної заяви громадян [8, с. 82], що є порушенням не тільки 
Конституції України, а й міжнародних актів, зокрема ст. 6 Конвенції про захист прав i основоположних свобод людини, якою передбачено розумний термін справедливого й відкритого розгляду справ у судах. Серед найважливіших проблем для України, на думку Л. Денісової, залишається забезпечення права громадян на справедливий суд і належне виконання судових рішень. Віддзеркаленням цього є статистика Європейського суду, який ухвалив уже багато рішень проти України, у понад 90\% яких констатовано порушення права на справедливий і своєчасний судовий розгляд і неналежне виконання судових рішень [9].

Діяльність Уповноваженого Верховної Ради України з прав людини розглянута в Проєктні ЄС Twinniнng № UA/47b «Впровадження кращого європейського досвідну 3 метою посилення інституційного потенціалу Секретаріату Уповноваженого Верховної Ради України з прав людини для захисту прав і свобод людини» (Порівняльний аналіз національного та європейського законодавства щодо діяльності Омбудсмена).

Відповідно до законодавства Уповноважений має певну юрисдикцію у сфері правосуддя. Щодо цього мандат Уповноваженого, як визначено правовими актами, стосується не лише моніторингу правосуддя, але й певного втручання у справи про порушення прав людини.

У міжнародному аспектні відносини між омбудсменами й судами детально розглянуті в Рекомендації ПАРС від 2003 р. № 1615 щодо інституції омбудсмена. Рекомендація, аналогічно до висновків Венеціанської комісії, відзначає різницю у відносинах омбудсмена 3 конституційними судами й звичайними судами: нейтралітет омбудсмена й той факт, що він або вона універсально поважаються як заявниками, так і суб'єктами розслідування, $€$ життєво важливим для нормального функціонування інституції омбудсмена. Асамблея вважає, що ці атрибути краще підтримуються за обмеження повноважень у сфері правозастосування моральним тиском, властивим публічній критиці, з доповідями про погане управління й подальшим політичним засудженням цього парламентом. Тому Асамблея вважає, що доступ омбудсменів до адміністративних і конституційних судів повинен обмежуватися зверненнями для тлумачення з правових питань, що стосуються мандатну або конкретних розслідувань, якщо омбудсмен не представляє окремого заявника, у якого немає прямого доступну до таких судів. Бажано, однак, щоб особи з достатнім правом на звернення до суду мали можливість безпосередньо звернутися до таких судів.
Асамблея вважає, що омбудсмени повинні мати суворо обмеженні повноваження наглядну над судами. Якщо обставини вимагають такої ролі, вона має обмежуватися тільки забезпеченням процесуальної ефективності й адміністративної коректності судової системи, тому можливість представляти фізичних осіб, за винятком випадків, коли ті не мають індивідуального права доступну до конкретного суду, ініціювати або втручатися в розгляд або повторне відкриття справ повинна виключатися.

Для зміцнення інституції омбудсмена в Європі ПАРЄ рекомендує забезпечити чіткий розподіл компетенцій між інституціями омбудсмена й судовим розглядом адміністративних актів, який повинен бути доступний принаймні у випадках порушення прав й основних свобод людини. Держав-членів знову заохочували встановити прямий доступ омбудсмена до Конституційного суду для того, щоб оскаржувати конституційність проблемного законодавства.

Рекомендації Венеціанської комісії щодо стосунків омбудсмена з судами також проводять різницю за тим, чи омбудсмену надані певні повноваження щодо юрисдикції конституційних судів або судів загальної й спеціалізованої юрисдикції. 3 точки зору захисту прав людини в Конституційному суді Венеціанська комісія вважає, що «мандат омбудсмена або правозахисника повинен включати в себе можливість звернення до Конституційного суду країни для абстрактного судження 3 питань щодо конституційності законів і правил або загальних адміністративних актів, які порушують питання, що стосуються прав і свобод людини. Омбудсмен повинен бути в змозі зробити це на власний розсуд або у відповідь на конкретні скарги до інституції».

Інше питання виникає під час обговорення відносин між офісом омбудсмена та звичайними судами. $\mathrm{y}$ цих випадках передбачається, що діяльність омбудсмена не повинна заважати судовій системні, а правове регулювання повинно чітко заявити, що суди виключаються з юрисдикції омбудсмена Обгрунтування для цього положення базується на ідеальній ролі інституції: «Модель, яку найбільш широко наслідують інституції омбудсмена або правозахисників, можна коротко описати як незалежну посадову особу, основною роллю якої є діяльність в ролі посередника між людьми й державною та місцевою адміністрацією, і можливість контролювати на цій посаді діяльність адміністративних органів через повноваження вимагати й мати доступ до інформації та звернення до адміністративних органів 
шляхом видачі рекомендацій на основі закону й справедливості в широкому сенсі, щоб протидіяти й виправляти порушення прав людини та випадки поганого управління». Для досягнення цієї мети інституціі вкрай важливо зберегти свій нейтралітет, відповідно, інституція не має втручатися в судовий процес або в судові справи [10].

Зазначена в п. 10 ст. 13 Закону України «Про Уповноваженого Верховної Ради України з прав людини» умова - неспроможність самого громадянина через фізичний стан, недосягнення повноліття, похилий вік чи з інших поважних причин звернутися до суду з заявою про захист прав і свобод - $є$ підставою для реалізації Уповноваженим права на звернення до суду по захист чужого інтересу, а не підставою самого права. Право на звернення Уповноваженого до суду по захист чужого інтересу передбачено ч. 2 ст. 56 Цивільного процесуального кодексу України (далі - ЦПК), де сказано, що з метою захисту прав і свобод людини й громадянина у випадках, установлених законом, Уповноважений Верховної Ради України $з$ прав людини може особисто або через свого представника звертатися до суду 3 позовом (заявою), брати участь у розгляді справ за його позовними заявами, а також на будь-якій стадії розгляду вступати в справу, провадження в якій відкрито за позовами (заявами) інших осіб, подавати апеляційну, касаційну скаргу, заяву про перегляд судового рішення за нововиявленими чи виключними обставинами, у тому числі у справі, провадження в якій відкрито за позовом (заявою) іншої особи. У такому разі Уповноважений повинен обгрунтувати суду неможливість особи самостійно здійснювати захист своїх інтересів. У зв'язку з цим невипадково в ч. 5 ст. 175 ЦПК «Позовна заява» зазначено, що в разі пред'явлення позову особою, якій законом надано право звертатися до суду в інтересах іншої особи, в заяві повинні бути зазначені підстави такого звернення, а не наявність права на звернення [11].

Виходячи 3 наведеного можна зробити висновок щодо підстав участі в цивільному процесі Уповноваженого: слід виділяти підстави, які мають загальний характер (ч. 2 ст. 4 і ч. 2 ст. 56 ЦПК), і підстави, якими обгрунтовується право Уповноваженого звертатися до суду з заявою про захист прав та інтересів конкретних осіб (п. 10 ст. 13 Закону України «Про Уповноваженого Верховної Ради України 3 прав людини»). Така класифікація підстав участі Уповноваженого в цивільному процесі має практичне значення: за відсутності підстав, які мають загальний характер, суддя взагалі не приймає справу до свого провадження, а за відсутності обгрунтування заяви щодо захисту прав чи свобод конкретної особи суддя може залишити таку заяву без руху для усунення цього недоліку.

Процесуальною формою участі Уповноваженого в цивільному процесі, як зазначено в ч. 2 ст. 56 ЦПК, є звернення до суду 3 позовом (заявою) про захист прав і свобод людини й громадянина.

Право українського омбудсмена звертатися до суду з заявою про захист прав і свобод громадян, а також особисто або через свого представника брати участь у судовому процесі у випадках і порядку, встановлених ЦПК, роблять Уповноваженого активним учасником судового провадження.

Загалом з аналізу змісту п. 10 ст. 13 Закону «Про Уповноваженого Верховної Ради України з прав людини» випливає, що форм участі Уповноваженого Верховної Ради України з прав людини в судовому процесі може існувати багато, але, враховуючи судову практику й норми інших спеціальних законів, які є складовими частинами законодавства, що визначає правовий статус цього органу, можемо говорити про можливість звернення до Уповноваженого Верховної Ради України з прав людини за ініціативою суду чи клопотанням сторони у справі для надання висновку [12].

Слід зазначити, що найбільший правозахисний потенціал Уповноваженого міститься в його праві звертатися до суду із заявою про захист прав і свобод осіб, які через фізичний стан, недосягнення повноліття, похилий вік, недієздатність або обмежену дієздатність не можуть цього зробити самостійно, а також особисто або через свого представника брати участь у судовому процесі.

3 цього питання в юридичній літературі зазначається, що хоча Уповноважений наділений правом брати участь у судових засіданнях і звертатися до суду з заявою про захист прав і свобод осіб, які через фізичний стан, недосягнення повноліття, похилий вік, недієздатність або обмежену дієздатність не можуть цього зробити самостійно, але законодавством України не врегульовано його статус: права українського Уповноваженого в кримінальних і цивільних процесах не визначено. У цьому зв'язку деякі науковці стверджують, що суди використовують цю обставину для обмеження ініціативи Уповноваженого щодо захисту прав громадян [13, с. $10 ; 3$, с. 400-401]

3 такою думкою не можна погодитися, оскільки вона, перш за все, суперечить чинному процесуальному законодавству. Уповноважений Верховної Ради з прав людини, 
як і інші органи й особи, яким законом надано право захищати права, свободи та інтереси інших осіб, належить до складу учасників справи (ст. 42 ЦПК), який має в цивільному процесі чітко визначений правовий статус. Він може звернутися до суду по захист прав і свобод фізичної особи у всіх видах проваджень, а саме пред'явити до суду позов, подати заяву про видачу судового наказу. Звернувшись до суду з заявою про захист прав і свобод громадянина, Уповноважений наділяється обсягом процесуальних прав та обов'язків особи, в інтересах якої він діє, за винятком права укладати мирову угоду (ст. ст. 43, 49 ЦПК). Водночас він може не лише брати участь в суді першої інстанції, але й подати апеляційну чи касаційну скаргу, а також заяву про перегляд судового рішення за нововиявленими чи виключними обставинами, у тому числі у справі, провадження в якій відкрито за позовом (заявою) іншої особи.

Водночас Уповноважений Верховної Ради України з прав людини повинен надати суду документи, які підтверджують наявність поважних причин, що унеможливлюють самостійне звернення цих осіб до суду для захисту своїх прав, свобод та інтересів.

Таким чином, громадяни вправі звертатися до Уповноваженого з прав людини з заявами щодо захисту їхніх прав та інтересів у судах. Однак одночасно 3 поданням такої заяви громадяни мають надати Уповноваженому з прав людини документи (оригінали або належним чином засвідчені копії), які підтверджують їхню неспроможність самостійно захищати свої інтереси в суді. За відсутності документів на підтвердження вказаної обставини Уповноважений з прав людини не буде допущенний судом до участі в судовому процесі.

Чинне законодавство не визначає перелік документів на підтвердження неспроможності особи самостійно захистити свої права й свободи, однак з огляду на зміст положень ст. 13 Закону України «Про Уповноваженого Верховної Ради України з прав людини» ці документи мають підтверджувати фізичний стан особи, недосягнення нею повноліття, похилий вік особи, недієздатність або обмежену дієздатність, які перешкоджають самостійному захисту особи в суді. Після отримання й дослідження наданих заявником документів Уповноваженим приймається рішення щодо звернення до суду в інтересах заявника [14].

\section{Висновки}

Не можна погодитися 3 висловленою в юридичній літературі думкою щодо доцільності обмеження компетенції Уповноваже- ного Верховної Ради з прав людини розглядом скарг лише на центральні органи державної влади [15, с. 187]. Виходячи 3 принципу поділу публічної влади на державну владу й місцеве самоврядування, публічну владу територіальних громад, на нашу думку, слід, навпаки, запровадити інститут регіонального уповноваженого (в областях) i місцевого уповноваженого 3 прав територіальної громади. Запровадження інституту місцевого уповноваженого з прав територіальної громади дало б змогу ліквідувати наявні прогалини у сфері функціонування механізмів захисту прав і свобод громадян, а також активізувати участь у цивільному процесі Уповноваженого Верховної Ради України з прав людини [16].

Вирішення цього питання в зазначеному вище порядку відповідає вимогам Парламентської асамблеї Ради Європи. Так, у п. 10 Рекомендації ПАРЕ стосовно інституції омбудсмана (Рекомендація № 1615 від 2003 р.) рекомендовано урядам держав членів Ради Свропи створити на національному рівні (а також на регіональному й місцевому рівнях, де це можливо), якщо вона ще не існує, інституцію з назвою, подібною до «парламентський / органу регіонального самоврядування / органу місцевого самоврядування омбудсмен», бажано 3 включенням відповідних положень до Конституції [17, c. 4-6].

\section{Список використаних джерел:}

1. Про Уповноваженого Верховної Ради України з прав людини : Закон України від 23 грудня 1997 р. № 776/97-ВР. Відомості Верховної Ради Украӥни. 1998. № 20. Ст. 99.

2. Justitieombudsmannen (JO). URL: http:// www.jo.se/sv/Om-JO/Historik/.

3. Марцеляк О.В. Інститут омбудсмана: теорія і практика : монографія. Харків : НУВС $2004.450 \mathrm{c}$.

4. Тенебаум А. Статус Уповноваженого Верховної Ради з прав людини і прогалини в законі. Право України. 1999. № 2. С. 101-103.

5. Ombudsman SA. URL: https://www. ombudsman.sa.gov.au/complaints/who-can-youcomplain-about/.

6. When to take a complaint to the ombudsman. URL: https://www.which.co.uk/consumerrights/advice/when-to-take-a-complaint-to-theombudsman.

7. Rafal Pelc. Polish model of relations between ombudsmen and judicial bodies. URL: http:// www.varuh-rs.si/fileadmin/user_upload/word/ Mednarodna_porocila/Relationship_between Ombudsmen_and_Judicial_Bodies/Poljska.doc.

8. Ненашев М.M. О критериях определения юридического интереса. Проблемные вопросы гражданского и арбитражного прочессов / под ред. 
Л.Ф. Лесницкой, М.А. Рожковой. Москва : Статут, 2008. C. $69-90$.

9. Л. Денісова. Кількість звернень до Уповноваженого. URL: http://www.ombudsman.gov.ua/ ua/all-news/pr/27318-tx-kilkist-zvernen-do-upovnovazhenogo-zi-skargami-na-porushennya-prava-n/.

10. Порівняльний аналіз національного і європейського законодавства щодо діяльності Омбудсмена. URL: http://www.twinning-ombudsman.org/ wp-content/uploads/2017/03/UA_Mission\%20 Report\%201.2.pdf.

11. Цивільний процесуальний кодекс України: науково-практичний коментар / за заг. ред. М.М. Ясинка. Київ : Алерта, 2018. 604 с.

12. Щодо необхідності отримання судами висновків Уповноваженого Верховної Ради України з прав людини у справах про дискримінацію : лист Вищого спеціалізованого суду України з розгляду цивільних і кримінальних справ від 16 лютого 2015 р. URL: http://consultant.parus.ua/?doc=09HHOF9E98.
13. Косюта М. Взаємозв'язок між діяльністю Уповноваженого Верховної Ради з прав людини та органів прокуратури у сфері правозахисту. Вісник прокуратури. 2002. № 3 (15). С. 10.

14. Повноваження Уповноваженого в судовому процесі. URL: http://www.ombudsman.gov.ua/ ua/page/secretariat/pravo-na-sudovij-zaxist/ povnovazhennya-upovnovazhenogo-u-sudovomuproczesi/.

15. Бойцова В.В. Нужен ли уполномоченный парламента по правам человека в России? Государство и право. 1993. № 2. С. 185-189.

16. Тимошевська I.П. Участь у цивільному процесі органів та осіб, яким законом надано право захищати права, свободи та інтереси інших осіб : монографія / Нац. юрид. ун-т ім. Ярослава Мудрого. Харків : Еспада, 2014. 174 c.

17. Рекомендації ПАРЄ. URL: https:// www.npu.gov.ua/activity/euvrointegracziya/ rekomendacziji-parje.html.

The article is devoted to the study of the legal status of the Commissioner for human rights as a participant in civil proceedings under the legislation of various States of the world and the problems of distinguishing the activities of the Ombudsman and the judicial system.

The author of the article analyzed the legal status of the Commissioner for human rights in General and as a member of the civil process in particular, according to the lawes of Sweden, Australia, Poland, UK, European Union, Ukraine, highlighted the features and characteristics of the legal regulation of its activities in each state.

In particular, the article focuses on the recommendations of the parliamentary Assembly of the Council of Europe on ensuring a clear distribution of competencies between the Ombudsman institutions and the judicial system. As well as recommendations of the Venice Commission on the relationship of the Ombudsman with national courts. According to the recommendations provided, the legal status of the Ombudsman in relations with the constitutional courts differs significantly from its legal status during interaction with courts of General jurisdiction. In particular, the focus is on maintaining the neutrality of the Ombudsman and ensuring the independence of the judicial system, first of all, we are talking about courts of General jurisdiction.

In addition, the author considers the peculiarities of legal regulation and the doctrinal definitions of the legal status of the Verkhovna Rada of Ukraine on human rights as a party to civil proceedings and argued that the human rights capacity of the Commissioner contained in his right to address in court with the statement for protection of the rights and freedoms of persons through a physical condition of failure to adulthood, old age, incapacity or limited legal capacity can't do it alone, and also personally or through his representative to participate in the judicial process.

The article summarizes that the Commissioner for human rights has the right to apply to the court for protection of violated rights and interests of citizens, but must justify to the court the inability of a person to independently protect their interests and provide relevant documents to confirm these circumstances, since the activities of the Ombudsman should not interfere with the judicial system and its interference in it should be minimal.

Key words: Commissioner for human rights, Ombudsman, civil procedure. 